\title{
COVID-19 from Wellington New Zealand
}

\author{
Ben Gray (D)
}

Received: 2 May 2020 / Accepted: 25 August 2020

(C) Journal of Bioethical Inquiry Pty Ltd. 2020

\begin{abstract}
This paper examines the role of bioethics in the successful control of COVID-19 in New Zealand. After the severe acute respiratory syndrome (SARS) coronavirus episode in Toronto researchers developed a framework of values and principles to articulate values that were already commonly accepted "in the community of its intended users," to be used to inform decision-making. New Zealand subsequently developed its own framework that was embedded in its Pandemic Influenza Plan. These formed the basis of the New Zealand response to COVID-19. This paper illustrates the ways in which the bioethical framework was reflected in the decisions and actions made by the government.
\end{abstract}

Keywords COVID-19 - Descriptive ethics $\cdot$ Pandemic planning

As of the time of writing, New Zealand is one of the only countries that has succeeded in eliminating COVID-19. This paper will examine the role that bioethics played in reaching this achievement.

Ashcroft wrote a polemic discussing the role of bioethicists in determining how to distribute World Health Organization funds to combat the AIDS epidemic in Africa (Ashcroft 2008). He reported that the only

B. Gray $(\bowtie)$

Primary Health Care and General Practice, University of Otago, Wellington, Wellington 6021, New Zealand

e-mail: ben.gray@otago.ac.nz agreement the group of international bioethicists reached was on the importance of good process. His view was that, in the absence of reaching substantive decisions, this made bioethics redundant. Following the severe acute respiratory syndrome (SARS) coronavirus epidemic in 2003, Thompson et al. $(2006,2)$ outlined the importance of bioethics input:

... the SARS experience in Toronto taught health care organisations, the costs of not addressing the ethical concerns are severe: loss of public trust, low hospital staff morale, confusion about roles and responsibilities, stigmatization of vulnerable communities, and misinformation.

They developed a framework guided by ethical decision-making processes and informed by ethical values. Like Ashcroft they emphasized the importance of fair process. Where Ashcroft felt the role of bioethics should be to make substantive decisions, Thompson et al. described a role for bioethics of developing a framework of values and principles. The aim was to articulate values that were already commonly accepted "in the community of its intended users" (Thompson et al. 2006) and it was to be used to inform decision-making. They described this as an exercise in applied, practical ethics. Following the SARS epidemic, the New Zealand National Ethics Advisory Committee (NEAC) published in 2007 the document "Getting Through Together: Ethical Values for a Pandemic." These were based around the Canadian example, with a focus on process and values (see National Ethics Advisory Committee 2007, 4-5 under "Table 1: Ethical values to inform how we make decisions" and 
"Table 2: Ethical values to inform what decisions we make").

Some of the values expressed in the pandemic document also appear in the Public Health Association code of ethics (Public Health Association of New Zealand 2012,5 ) with a slightly different translation, including:

Manaakitanga is behaviour that acknowledges the mana [prestige] of others as having equal or greater importance than one's own, through expression of aroha [love], hospitality, generosity and mutual respect. In doing so, all parties are elevated and our status is enhanced, building through humility and the act of giving.

Whanaungatanga underpins the social organisation of whanau [family], hapu [subtribe] and iwi [tribe] and includes rights and reciprocal obligations consistent with being part of a collective. It is the principle which binds individuals to the wider group and affirms the value of the collective. Whanaungatanga is inter-dependence with each other and recognition that the people are our wealth.
As with Toronto, this was an exercise in practical/ applied ethics; a description of the values of the "community of intended users." A significant difference between the New Zealand framework and the Toronto framework was the inclusion of Māori ethical concepts. Māori, the indigenous people of New Zealand, comprise around 16 per cent of the population (Statistics New Zealand 2018). There has been a significant Māori cultural renaissance in New Zealand over the past forty years (Taonui 2017), that has led to a broad acceptance that Māori values are an essential part of ethical decision-making in New Zealand. The NEAC "National Ethical Standards for Health and Disability Research and Quality Improvement" (National Ethics Advisory Committee 2019) and the code of ethics of the NZ Public Health Association (Public Health Association of New Zealand 2012) each have two sets of principles that sit alongside each other: a Māori list and a generic list. There is a lot of overlap but also some distinctive differences between the lists. While this analysis is based on there being a distinct Māori community, in reality there has been much merging of cultural values;
Table 1 Ethical values to inform how we make decisions

\begin{tabular}{|c|c|}
\hline Ethical value & Actions associated with the value \\
\hline Inclusiveness & $\begin{array}{l}\text {-including those who will be affected by the decision } \\
\text {-including people from all cultures and communities } \\
\text {-taking everyone's contribution seriously } \\
\text { •striving for acceptance of an agreed decision-making process, even by those } \\
\text { who might not agree } \\
\text { with the particular decision made }\end{array}$ \\
\hline Openness & $\begin{array}{l}\text { - letting others know what decisions need to be made, how they } \\
\text { will be made and on what basis they will be made } \\
\text { - letting others know what decisions have been made and why } \\
\text { •letting others know what will come next } \\
\text { • being seen to be fair }\end{array}$ \\
\hline Reasonableness & $\begin{array}{l}\text {-working with alternative options and ways of thinking } \\
\text { •working with and reflecting cultural diversity } \\
\text { •using a fair process to make decisions } \\
\text { •basing decisions on shared values and best evidence }\end{array}$ \\
\hline Responsiveness & $\begin{array}{l}\text { - being willing to make changes and be innovative } \\
\text { •changing when relevant information or the context changes } \\
\text { •enabling others to contribute whenever we (and they) can } \\
\text { •enabling others to challenge our decisions and actions }\end{array}$ \\
\hline Responsibleness & $\begin{array}{l}\text {-acting on our responsibility to others for our decisions and actions } \\
\text { •helping others to take responsibility for their decisions and actions }\end{array}$ \\
\hline
\end{tabular}


Table 2 Ethical Values to inform what decisions we make

\begin{tabular}{|c|c|}
\hline Ethical value & Actions associated with the value \\
\hline Minimising harm & $\begin{array}{l}\text {-not harming others } \\
\text {-protecting one another from harm } \\
\text { •accepting restrictions on our freedom when needed to protect others }\end{array}$ \\
\hline Respect & •recognising that every person matters and treating people accordingly \\
\hline Manaakitanga & $\begin{array}{l}\text {-supporting others to make their own decisions whenever possible } \\
\text {-supporting those best placed to make decisions for people who cannot make their own decisions } \\
\text {-restricting freedom as little as possible, but as fairly as possible, if freedom must be restricted for the public good }\end{array}$ \\
\hline Fairness & $\begin{array}{l}\text {-ensuring everyone gets a fair go } \\
\text {-prioritising fairly when there are not enough resources for all to get the services they need } \\
\text {-supporting others to get what they are entitled to } \\
\text {-minimising inequalities }\end{array}$ \\
\hline $\begin{array}{l}\text { Neighbourliness } \\
\text { whānaungatanga }\end{array}$ & $\begin{array}{l}\text {-helping and caring for our neighbours and friends } \\
\text { •helping and caring for our family/whānau and relations } \\
\text { •working together when there is a need to be met }\end{array}$ \\
\hline Reciprocity & $\begin{array}{l}\text {-helping one another } \\
\text {-acting on any social standing or special responsibilities we may have, such as those associated with professionalism } \\
\text {-agreeing to extra support for those who have extra responsibilities to care for others }\end{array}$ \\
\hline Unity Kotahitanga & $\begin{array}{l}\text {-being committed to getting through the situation together } \\
\text { •showing our commitment to strengthening individuals and communities }\end{array}$ \\
\hline
\end{tabular}

the development of an Aotearoa ${ }^{1} / \mathrm{New}$ Zealand culture. There is increasing use of Māori language within the mainstream media and many Māori cultural practices are being adopted by the wider Aotearoa/New Zealand community, the most famous being the Haka performed by the rugby All Black team before a match.

After the 2009 H1N1 influenza pandemic, the New Zealand Pandemic Influenza Plan (NZPIP) was developed, and updated in 2017 (Ministry of Health 2017). The plan was written with influenza as the main focus, but it was noted that the plan would be applicable for other respiratory infections such as, for example, SARS. Ethical issues were top of the key issues list in the NZPIP (Ministry of Health 2017, 15):

People are more likely to accept difficult decisions if decision-making processes are open and transparent, reasonable, inclusive and responsive, with clear lines of accountability. Decision-making processes are also more likely to be acceptable if they are based on agreed, core ethical values.

It also noted that:

Some pandemic programmes must be implemented swiftly if they are to be effective, and some will

\footnotetext{
${ }^{1}$ Aotearoa is the Māori name for the country of New Zealand.
}

have ethical components that need to be considered in real time. It will not always be effective to rely on usual processes.

In short, the foundational principles of the "Getting Through Together: Ethical Values for a Pandemic" document (National Ethics Advisory Committee 2007) are deeply embedded in the current New Zealand Pandemic Influenza Plan.

\section{The New Zealand Response To COVID-19}

In responding to COVID-19, a clear delineation was made between the science on which actions were based (represented by Director General of Health Dr Ashley Bloomfield), the ethical foundation on which decisions were based (that were embedded in the planning), and the politics of what was likely to be possible (led by Prime Minister Jacinda Ardern).

It was clear by mid-March 2020 that the option of no policy response had a high risk of large numbers of infections and deaths, and a collapse of the local health system. A choice had to be made as to what to do and our government decided to "Go hard, go early." On March 26, 2020, a high level of community lockdown was imposed (Level 4), allowing only essential services to operate. Details of what each level entailed are 
published on the NZ government COVID-19 website. (New Zealand Government 2020). After one month at Level 4 restrictions, a decision was made to extend it for a further week before moving to Level 3. The basis of the decision was clearly signalled in advance and the extension was needed to ensure that capacity for contact tracing would be capable of managing the increased cases that might happen after restrictions loosened. These actions required a combination of the science (detail on contact tracing capacity, numbers of cases, amount of community spread), the ethical framework (described below), and the politics of whether the country would get behind the decision. The last two are of course linked in that if the ethical framework used is one that is shared by the community then it is more likely members will follow the rules. We moved to Level 2 on May 13 and finally to Level 1 on June 92020.

Good communication was a central element of the strategy. From mid-March until mid-May there were daily media briefings from the Prime Minister (PM) or other government ministers and the Director General of Health or other public servants. ${ }^{2}$ I have selected some quotes from these briefings to illustrate the values articulated in ethical frameworks at work.

Unity/Kotahitanga

We have the opportunity to do something no other country has achieved-elimination of the virus - but it will continue to need a team of five million behind it. (PM Jacinda Ardern, April 16, 2020)

\section{Reciprocity}

Today, I can confirm that myself, Government Ministers, and Public Service chief executives will take a 20 percent pay cut for the next six months (PM Jacinda Ardern, April 15, 2020)

While acknowledging that the sum would make little practical difference to the government budget it was couched as an example of leadership and described alongside the sacrifices that many others had made.

Neighbourliness/whānaungatanga

\footnotetext{
${ }^{2}$ Video and transcripts of briefings and copies of media statements are listed by date on the Ministry of Health website "COVID-19 (novel coronavirus) - News and media updates" section, available at https://www.health.govt.nz/our-work/diseases-and-conditions/covid19-novel-coronavirus/covid-19-novel-coronavirus-news-and-mediaupdates. Accessed July 23, 2020.
}

Please be strong, be kind, and unite against COVID-19. (PM Jacinda Ardern, March 21, 2020)

We are seeking physical separation not social separation-reach out to people and most importantly be kind. (Director General of Health Ashley Bloomfield, March 29, 2020)

Throughout her briefings Prime Minister Ardern emphasized kindness and compassion. Particular emphasis was put on being kind to stressed supermarket workers and other front line staff.

Fairness

[The Ministry of Education] is also working with schools to identify students who do not have a device at home. It will deliver as many devices and materials as possible to students who will benefit the most. (Education package April 8th)

This was a clear commitment to addressing inequalities. An important argument in favour of elimination was that in the event that the virus spread the impact would be greater on more disadvantaged communities (Wilson et al. 2020).

Openness

Now, I share this with you because we have been open and transparent throughout this fight against COVID-19, and I personally believe really strongly that it is only fair. Since we are all in this together, we need to all keep working together for success, and that means us sharing with everyone the factors we'll be taking into consideration and the data we use. (PM Jacinda Ardern, April 19, 2020)

The PM frequently emphasized the importance of transparency. She signalled in advance when big decisions would be made and what the basis of those judgements would be. There were several Facebook question and answer sessions with the public. The media had a lot of time for questions and answers after each release, that were answered clearly and with a commitment to find information if not immediately available ... which was then followed through. The PM made it very clear that the goal was not just controlling the epidemic but overall well-being.

During that time, our focus has been to protect the health of New Zealanders. Alongside this, we've 
acted to cushion the economic blow as well...

(PM Jacinda Ardern, April 19, 2020)

In their study of community responses to communication campaigns for Influenza A, Gray et al. identified that people wanted "messages about specific actions they could take ... [and] transparent and factual communication where both good and bad news is conveyed by people who they could trust" (Gray et al. 2012). Public approval ratings suggest Prime Minister Ardern and Director General of Health Bloomfield mostly achieved this. Jacinda Ardern's preferred Prime Minister rating on May 21, 2020, had gone up 21 per cent, to 63 per cent, the highest of any Prime Minister in the twenty-five years the poll has been conducted (Colmar Brunton 2020).

Google COVID mobility data showed that New Zealanders adhered to lockdown measures better than in most countries (Ritchie 2020). There was little in the way of enforcement required to achieve this. For a total population of five million, between March 23 and April 23, 2020 (during the Level 4 lockdown):

... police recorded 4,452 breaches of the Civil Defence Emergency Management or Health Act ... 477 prosecutions, 3,844 warnings, 131 youth referrals. (Commissioner of Police, April 23, 2020 briefing)

The reality of steering through a pandemic is that there are myriad decisions to be made, in real time with insufficient information. There has been much debate in the media around these decisions. Many of the ideas raised have later been adopted as policy and there has been wide consultation with many sector groups. The approach taken of widely sharing available information as it comes to hand, having a clear sense of the ethical basis on which decisions will be made, and holding the trust and commitment of the population has been successful.

\section{Conclusion}

New Zealand is fortunate in its experience of COVID19 . We are a relatively sparsely populated island nation, although with a (previously) large tourism industry. The pandemic started far from our shores and we had time to make choices on how to respond. We have significant capacity in academic public health expertise but had to rapidly upscale our on-the-ground public health capacity to test and contact trace. We had developed a detailed pandemic plan with an explicit ethical framework. At the time of writing, New Zealand had avoided widespread infection and death. Bioethics articulated a framework that reflected the values and beliefs of the people who live here. Content specialist colleagues in clinical medicine, public health, modelling, economics, and many others interpreted the often uncertain information and provided good communications on which to base decisions. Our politicians, in particular Prime Minister, provided the leadership in making difficult decisions based on the ethical framework and scientific information, while building and maintaining the trust of the population necessary to implement them. Bioethics played an important role in eliminating COVID-19 from New Zealand.

\section{References}

Ashcroft, R.. 2008. Fair Process and the Redundancy of Bioethics: A Polemic. Public Health Ethics 1(1): 3-9.

Colmar Brunton. 2020. 1 News Colmar Brunton Poll 16-20 May 2020. https://www.colmarbrunton.co.nz/what-wedo/1-news-poll/. .

Gray, L., C. MacDonald, B. Mackie, et al. 2012. Community responses to communication campaigns for influenza A (H1N1): a focus group study. BMC Public Health 12:205. Doi: https://doi.org/10.1186/1471-2458-12-205

Ministry of Health. 2017. New Zealand Influenza Pandemic Plan: a Framework for Action. Wellington:New Zealand Ministry of Health. https://www.health.govt.nz/publication/newzealand-influenza-pandemic-plan-framework-action. Accessed April 13. 2020.

National Ethics Advisory Committee. 2007. Getting Through Together: Ethical Values for a Pandemic. Wellington: New Zealand Ministry of Health. http://neac.health.govt. $\mathrm{nz} /$ system/files/documents/publications/getting-throughtogether-jul07.pdf. .

2019. National Ethical Standards for Health and Disability Research and Quality Improvement. Wellington: New Zealand. https://neac.health.govt.nz/publications-andresources/neac-publications/national-ethical-standardshealth-and-disability. Accessed 23 July 2020.

New Zealand Government. 2020. COVID-19 Alert Level system. https://covid19.govt.nz/updates-and-resources/legislationand-key-documents/. Accessed July 23. 2020.

Public Health Association of New Zealand. 2012. Te Ture Whakaruruhau-Code Of Ethical Principles For Public Health in Aotearoa New Zealand.. https://www.pha.org. nz/page-18201. .

Ritchie, H.. 2020. Google Mobility Trends: How has the pandemic changed the movement of people around the world?. Our World in Data. Oxford: Global Change Data Lab and the 
University of Oxford. https://ourworldindata.org/covidmobility-trends. .

Statistics New Zealand. 2018. Quick stats about ethnicity for New Zealand (2018 Census).. New Zealand Government. https://www.stats.govt.nz/tools/2018-census-placesummaries/new-zealand. .

Taonui, R.. 2017. 'Ngā tuakiri hōu—new Māori identities. Te Ara-The encyclopedia of New Zealand. Wellington: Manatū Taonga Ministry for Culture and Heritage. https://teara.govt.nz/en/nga-tuakiri-hou-new-maoriidentities. Accessed Ju;ly 23, 2020.

Thompson, A. K., K. Faith, J. L. Gibson, and R. E. G. Upshur. 2006. Pandemic influenza preparedness: an ethical framework to guide decision-making. BMC Medical Ethics 7:12. 10.1186/1472-6939-7-12. Accessed July 23. 2020.
Wilson N, L. Telfar Barnard, A. Kvalsvig, and M. Baker. 2020. Potential Health Impacts from the COVID-19 Pandemic for New Zealand if Eradication Fails: Report to the NZ Ministry of Health. Wellington: University of Otago Wellington. https://www.health.govt. $\mathrm{nz} /$ system/files/documents/publications/report_for moh_-_covid-19_pandemic_nz_final.pdf Accessed July 23.2020.

Publisher's note Springer Nature remains neutral with regard to jurisdictional claims in published maps and institutional affiliations. 